\section{Concrete evidence that volcanoes can be stopped}

SIR - In your News story "Volcano gets choke chains to slow mud" (Nature 445, 470; 2007), you cite some physicists who had not heard of using concrete balls and linked chain to attempt to plug a mud geyser. The US Navy (in which I was then a commander), the Italian Navy and the US Marine Corps used exactly this approach successfully in Sicily, in April-May 1992, to slow and eventually redirect lava flow from Mount Etna that was threatening the small village of Zafferana.

We came up with this plan while talking to an Italian geologist. He spoke no English and I spoke no Italian, but I have a bachelor's degree in geology and that helped a lot. We communicated on the back of a napkin while seated at a small restaurant at the ski lodge that became our base of operations. The navy units involved tried several different ways to place large decommissioned anti-terrorist barriers into a vent approximately 8,000 feet (2,440 metres) up the side of the volcano.

The first plan was to drop individual barriers into the vent, but that failed because of insufficient quantity, and the heat simply ignited the concrete. We then built a very large slide and were going to stack barriers on the slide and slip it into the vent. The slide was constructed but was impossible to move to the vent as mountain winds forced it into the path of the aircraft. (I filmed it on video and it is rather dramatic.)

Our third plan, which eventually worked, involved linking several dozen barriers together with asbestos-wrapped anchor chain and placing them in position around the vent. Additional concrete 'Dempster Dumpster' pads were placed directly over the vent on a net formed of anchor chain. When the entire assembly was in place it was blown into the vent using plastic explosive. US Navy and US Marine Corps CH-53E helicopters were used to place the barriers and transport the Italian explosives ordinance team required to place the explosives. The lava tube carrying lava down the mountain to the vicinity of Zafferana collapsed when flow was interrupted. That removed the immediate danger.

The long-term solution was to drive a bulldozer up the mountain, dig a very large canal and blow out the side of the vent. We had to change the engine on the bulldozer when we finally got it in place, as moving it up the hill destroyed the original engine.

The operation was extremely hazardous and at times conducted in blinding snowstorms. Aircrews had to contend with the noxious mix of gases as they hovered directly over the vents for long periods of time. Several US Navy and US Marine Corps aircrews were awarded air medals for their performance. The entire operation was designed, developed and coordinated by the Air Operation Department at Naval Air Station Sigonella, Sicily, under the command of Captain Michael Bruner. I had the privilege of running the Air Ops Department during the Etna operation and have 35 air crew hours logged in the $\mathrm{CH}$-53Es operating on the mountain.

John Carpenter

Annandale, Virginia 22003, USA

See News Feature, page 812.

\section{Newspaper scare headlines can be counter-productive}

SIR - Your coverage of the report from the Intergovernmental Panel on Climate Change (IPCC) working group included some exemplary Editorial and News headlines: "Light at the end of the tunnel", "What we don't know about climate change" and "From words to action" (Nature 445, $567 \& 578-583$; 2007). These convey the message about knowledge, ignorance and action that would be expected from a leading journal writing for a scientific readership.

Communicating science to wider, public audiences, however - in this case on matters of important public policy - is an art that requires careful message management and tone setting. It seems that confident and salient science, as presented by the IPCC, may be received by the public in non-productive ways, depending on the intervening media.

With this in mind, I examined the coverage of the IPCC report in the ten main national UK newspapers for Saturday 3 February, the day after the report was released. Only one newspaper failed to run at least one story on the report (one newspaper ran seven stories), but what was most striking was the tone.

The four UK 'quality' newspapers all ran front-page headlines conveying a message of rising anxiety: "Final warning", "Worse than we thought", "New fears on climate raise heat on leaders" and "Only man can stop climate disaster". And all nine newspapers introduced one or more of the adjectives "catastrophic", "shocking", "terrifying" or "devastating" in their various qualifications of climate change. Yet none of these words exist in the report, nor were they used in the scientists' presentations in Paris. Added to the frontpage vocabulary of "final", "fears", "worse" and "disaster", they offer an insight into the likely response of the 20 million Britons who read these newspapers.

In contrast, an online search of some leading newspapers in the United States suggests a different media discourse. Thus, on the same day, one finds these headlines: "UN climate panel says warming is manmade", "New tack on global warming", "Warming report builds support for action" and "The basics: ever firmer statements on global warming". This suggests a more neutral representation in the United States of the IPCC's key message, and a tone that facilitates a less loaded or frenzied debate about options for action.

Campaigners, media and some scientists seem to be appealing to fear in order to generate a sense of urgency. If they want to engage the public in responding to climate change, this is unreliable at best and counterproductive at worst. As Susanne Moser and Lisa Dilling point out in Creating a Climate for Change: Communicating Climate Change and Facilitating Social Change (Cambridge Univ. Press, 2007), such appeals often lead to denial, paralysis, apathy or even perverse reactive behaviour.

The journey from producing confident assessments of scientific knowledge to a destination of induced social change is a tortuous one, fraught with dangers and many blind alleys. The challenging policy choices that lie ahead will not be well served by the type of loaded reporting of science seen in the UK media described above.

\section{Mike Hulme}

Tyndall Centre, School of Environmental Sciences, University of East Anglia, Norwich NR4 7TJ, UK

\section{Niche drugs aren't a cheap alternative to blockbusters}

SIR - Your Editorial "A changing drug supply” (Nature 445, 460; 2007) captures some of the realities facing the pharmaceutical industry in the post-blockbuster era.

However, tailored drugs with smaller targeted populations are not necessarily cheaper to develop. If this were true, the pharmaceutical industry would have migrated to this model long ago.

Drugs targeted at smaller populations still need to be discovered, validated in preclinical models, formulated, and shown to be efficacious and safe in patients - in short, the same requirements as for a potential blockbuster drug. Depending on the disease and a multitude of factors, some clinical trials could potentially be less expensive for a small population, but this is unlikely to be the norm. Going down this path does not guarantee a lack of competition either: as revenue pressures build, more companies will compete for these niche populations. Targeting small populations is not a panacea for the industry illness, just as there are none for human illness.

\section{W. Ross Tracey}

11 North Ledge Rock Road, Niantic,

Connecticut 06357, USA

Contributions to Correspondence may

be submitted to corres@nature.com.

Published contributions are edited. 